\title{
POLITENESS STRATEGIES PERFORMED BY TEACHERS TO EFFECTIVELY ASSIST CHILDREN WITH AUTISM IN THEIR LEARNING PROCESS
}

\author{
Sugini ${ }^{1}$, Djatmika ${ }^{1}$, Maryadi ${ }^{1}$ \\ ${ }^{1}$ English Department/ Linguistics Postgraduate Program, Universitas Sebelas Maret \\ Emai:djatmi@yahoo.com
}

\begin{abstract}
ABSTRAK
The paper discusses the politeness strategies conducted by teachers of autism centre in Surakarta in supporting them doing their jobs effectively. They are professionals who care and treat children with autism for their cognitive as well as psychomotoric development. Data were collected from four learning processes performed by four different female teachers with a different child for each. The analysis was carried out to see how politeness strategies selected by the teachers help them in performing effective assisting and learning process for the kids. The results show that politeness strategies were conducted by the teachers in two modes - verbally and non-verbally. They were exploited to accommodate the skill transfer to the children with autism effectively. The autism condition of each child governed each teacher to select the types of the politeness - in which bald on strategy dominated the exploitation, followed by positive and negative politeness. In addition, no teacher chose off record strategy for her class. This exploitation is considered effective due to the exceptional condition of the children. Clear and direct utterances which encourage their self esteem are good choice for them. Such utterances in that features can be accommodated by those three types of politeness strategies in either verbal or non-verbal mode.
\end{abstract}

Keywords: politeness strategy, children with autism, assisting, learning, interaction

\section{INTRODUCTION}

Minding and assisting children with autism requires several types of competencies. One of the skills teachers for these exceptional children should have is language exploitation to carry out the process of therapy as well as the process of learning for them. A good strategy in using the language can help them initiate verbal communication with the children. Such an initiation plays an important role to build up further interaction with such children in which knowledge and skills transfers are conducted from the teachers to their pupils. The phenomenon is in line with what Wenar (2004) has suggested, that in general children with autism do not speak communicatively. It is further elaborated that the children commonly show their incapability in verbal interaction with other people (Safaria, 2005). They tend to imitate what other people say and do, they wrongly select pronouns, and they are not good at reciprocal interaction with other people.

Children with autism are those who suffer a disfunction of brain development which is characterized by their incapability in making social interaction and in making communication with other people. These children also show slow academic development (Pamuji, 2007). Autism, according to the time of appearance, is classified into two types, namely on-born and regression autism. The former actually can be identified when a baby reaches the age of 4 months, even 
though commonly parents have realized that that something wrong happens to their baby at the age of 2 years. Meanwhile, the latter happens to a baby who grows normaly from the age of zero month to 2 years. S/he then develops differently from normal children. Even several skills that have developed gradually disappear.

Assisting children with autism to communicate with other people is not a good job because in general they do not understand what is being communicated (Schuler \& Fletcher:2003). This is further supported by the fact that children suffering autism tend to have uncontrolled behavior influencing the process of communication such as being aggressive, or hurting themselves to show that they need something, they need attention, or they object to changed routines or to a scheduled agenda.

It is further suggested by Shulman (2003) that children suffering autism experience difficulties in developing their imagination and doing social role-play. On that account, it is assumed that the problem they have in using language is perhaps related to the lack of opportunity they have in using the language for playing with other kids. They tend to repeat any language unit someone has produced to interact with them; however, the children do not use the unit to be meaningful in certain speech events they have. Furthermore, they also repeat the same language unit many times in a similar intonation without non-verbal support to make the language unit have meaning (Wetherby et.al.: 2000).

As the process of language acquisition is closely related to the nueron system, children with autism in general get problems in their language development. Hill \& Kodituuwakku (2003) suggested that these children have got problems in their frontal lobe in the cerebral cortext. This is located in the right hemisphere, so that the condition also influences mental development. This condition has been considered to be the reason why most children suffering autism have slower language development than normal children.

The problem in making children with autism communicate using language relates to combining the spoken production and the auditorial process. In general, they do not respond to utterances forwarded to them by a speaker, or the responses are provided but not in a consistent pattern. They also have difficulty in initiating an exchange and in maintaining the topic of a conversation (Shulman, 2003). A study conducted by Ratey (as reported by Fletcher \& Schuler, 2003) claimed that this is the biological condition which influences the process of communication between children with autism and normal children. Therefore, the study recommended to speaking slowly at a slow pace and in a clear manner to a child suffering from autism.

\section{POLITENESS STRATEGIES FOR MINDING}

Meanwhile, politeness is related to the concept of face referring to what Goffman in Brown \& Levinson (1987) have suggested that face is something that is emotionally invested, and that can be lost, maintained, or enhanced, and must be constantly attended to in interaction. In daily human interaction, such a concept has been become routines. A person who is involved in an interaction will try to maintain and even increase her/his image, reputation and self-esteem. Academic and also other qualification someone pursues is in general due to the process of such an attempt. In her/ his mind, the higher the education level someone obtains, the better image and reputation she/ he has. In general, face is classified into two of types - positive and negative. The former is related to the need of approval for someone's existence and reputation, while the latter shows that everyone wants to be free from any imposition given by other people.

Someone who is aware with such types of face above will consider strategies of politeness in any interaction in which she/he is involved. With positive politeness, she/he attends her/his interlocutor in terms of her/his positive image and reputation, while with the negative one she/he avoids any action that gives burden or imposition to her/him, or 'trespasses' her/ his territory. To design utterances in politeness strategies, Brown \& Levinson (1987) suggested several formulas which are related to the concept of positive and negative face politeness and face threatening act such as strategies for bald on, positive politeness, negative politeness, and off record mode. The strategies in bald on mode is usually executed by a person with higher power over someone else. For example, 
a direct command delivered by a mother to her daughter will be accepted properly because of the legitimate power she has. Meanwhile, several strategies have been recommended by Brown \& Levinson (1987) for positive, negative, and off record politeness. They suggested fifteen (15) super strategies for positive face, ten (10) strategies for negative face, and fourteen (14) strategies for off record.

Supporting the politeness strategies in interaction is accommodated by the exploitation of language. Moreover, teachers should also consider non verbal behaviour for the interaction, thus the term systemic for the language exploitation is considered to be related to the selected multimodal systems the teachers have, at least the verbal as well as the non-verbal behaviour they perform in the teaching process. In this speech event, the former is more associated with what is termed lexicogrammar - the strategy for making grammatical constructions and the choice of words used in the interaction. Meanwhile, the latter is seen in the way the teachers use body language, facial gestures, intonation, and some paralinguistic aspects such as intonation, pitch, tone, and so on. Respondents of the research for this article are teachers for children with autism. In performing their jobs, they combine both verbal and nonverbal resources for designing politeness strategies to support the process of minding and assisting such children learning skills.

Mood structure also becomes another focus of analysis in this study, as through the grammar quality how the teachers treat the children can be realized. In the teaching session, one message is encoded by the teachers in a clause, and within this clause a certain act is accommodated. Therefore, if one language unit has two messages to send, it will be constructed in two clauses-each accommodates one act. The acts in clauses are the things which are used to negotiate, to give, to demand, and to command, and so on. As a clause is used for negotiation, the grammatical construction should be appropriate with the function it has.

Systemically, a grammatical construction for a clause consists of a subject, finite, predicator, and adjunct. In general, a nominal group or a clause behaving like a nominal group is positioned as a subject of a clause, while finite is a part of a verbal group showing polarity, modality and tense. These two elements play the most important part to make the clause function appropriately in the negotiation related to the intention of the speaker who makes it (Halliday, 1994: 70-71; Eggins, 1994: 154; Gerot \& Wignell, 1995).

In addition to the grammatical construction used for clauses in the interaction, the choice of words also influences the effective language exploitation for the teachers in handing a class for children with autism. There are types of words that should be considered to be useful such as common or daily words, nominalization, technical terms, and metaphors. A wise teacher who treats children who have difficulties in communicating will select words that are considered easily understood by them. Therefore, daily and easy words are the best choice for teachers in building interaction with children, but not the other types of words.

Furthermore, to support all verbal strategies that have been effectively designed, a teacher of children suffering autism should also consider non-verbal behaviour. The mental condition of the children becomes the reason why, for example, one utterance of a command should go along with appropriate intonation, clarity of the speech, as well as body language. If this is so, such a teacher has performed a kind of multimodal encoding to the children. In line with this phenomenon, Levine \& Scollon (2004) have suggested that:

"All discourse is multimodal, that is, language in use, whether this is in the form of spoken language or text, is always and inevitably constructed across multiple modes of communication, including speech and gesture not just in spoken language but through such 'contextual' phenomena as the use of the physical spaces in which we carry out our discursive action"

The paper is based on a small project to see the quality of politeness strategies performed by teachers of children with autism in an autism center in Surakarta. A pragmatic analysis was conducted to investigate the effective politeness strategies in supporting the teachers transferring skills to such children in learning sessions. As treatment for children with autism has been focused more on the psychological and neurological aspects rather than 
the linguistic one, this study would like to elaborate on how the linguistic aspect is as important as the other two when considering such a treatment. The results of the analysis are expected to become a good model of interaction strategy for teachers as well as parents of children with autism in minding and assisting them.

Four learning sessions - each was conducted by a different female teacher-were selected and videotaped as the source of data. Utterances executed by the teachers were then collected from their interaction with the children with autism. All of them were analyzed to see the types of speech acts they used and the politeness strategies they created. Analysis was also carried out to see the politeness strategies executed by the teacher non-verbally. From the analysis, effective politeness strategies are suggested those teachers as well as other teachers who are professionals on handling learning process for exceptional children, especially those who are with autism.

\section{DISCUSSION}

In each of the interactions, each female teacher performs differently in terms of the number of turn, the number and types of speech act she has for one turn and also types of politeness strategies both in verbal and non-verbal mode. The turn and the types of act for one act are considerably related to the autism condition each child possesses. The following table displays the performance of the teachers in general.

Table 1

Teachers' Pragmatic Contribution in Interaction

\begin{tabular}{lcccccccc}
\hline Name & $\begin{array}{c}\text { Autism } \\
\text { Condition }\end{array}$ & $\begin{array}{c}\text { Number of } \\
\text { turns }\end{array}$ & $\begin{array}{c}\text { Number of } \\
\text { Acts }\end{array}$ & Bald on & Positive & Negative & Off record & $\begin{array}{c}\text { Non } \\
\text { verbal }\end{array}$ \\
\hline Miss Dini & light & 68 & 117 & 76 & 68 & 54 & 0 & 13 \\
Miss Ratna & severe & 48 & 141 & 55 & 78 & 33 & 0 & 10 \\
Miss Tyas & medium & 77 & 138 & 58 & 37 & 40 & 0 & 23 \\
Miss Iis & severe & 72 & 243 & 55 & 68 & 32 & 0 & 32 \\
\hline
\end{tabular}

Table 1 suggests that the condition of the children can have a role in determining the number of acts the teacher produced in the interaction. The more serious the condition is, the more acts the teachers will produce in accommodating the learning process.

The most interesting features of the language exploitation in the interactions are demonstrated by the types of act selected by the teachers. Along the interactions they tend to only exploit three types of speech acts as under pragmatists' classification (such as Thomas, 1995; Verschueren, 1999) such as assertive, directive and expressive. Commissive and performative speech acts do not appear in the interactons. Under the first type of speech act, the speech acts of telling and acknowledging dominate the usage. These two acts are almost used in all exchanges in the interaction. Mostly the former is exploited by the teachers to tell about certain on-coming activity after one has been done, while the latter is executed after the children provide an answer for a question or a non-verbal performance for an instruction from the teachers.

The second classification of the speech act is realized by the act of asking, commanding, and inviting in which the first two are dominative through the interaction. This fact is clearly related to the job of the teachers; as they want to train the kids with academic as well as psychomotoric skills, making the child do verbal as well as non verbal responses related to provided problems, as well as making them provide answers for the problems, such three acts are then selected and carried out by the teachers. By asking, the teachers provide questions to the children which are not genuine but they check the students' understanding by using such utterances constructed in interrogative forms, instead. Meanwhile, with a command the teachers make the kids give spoken responses to the academic problems given or to make them write down the answers, or to make them do certain physical actions such holding a pen, taking a book, crawling, raising their hands, and so on. When an exercise has been finished by the children, and 
the teachers want to proceed to the next one, they deliver an invitation for it.

Three types of expressive speech acts which are dominantly selected by the teachers in the interactions among others are praising, cheering, and celebrating. The first one is performed by the teachers to appreciate what the kids have done or accomplished and at the same time they reinforce the students with the process of learning. This kind of speech act is very dominant in the interaction. The teachers almost always use it in all exchanges in the interaction. Meanwhile, to appreciate what the children have done and at the same time congratulating them for the achievement, the teachers conduct a cheering act. This often goes together with an appreciation in which the teachers appreciate the achievement of the child by performing a give me ten action or tossing.

These three classifications of speech acts selected by the teachers very often go together in one exchange. Put in other words, they are often used in combination - for example, after a teacher delivers a mathematic problem in the form of a question, she accepts the answer given by the child, and then expressively she praises him for the correct answer, and sometimes she continues it with a cheer as well as a celebration with the child. The following table displays the types of speech act performed by the teachers.

Table 2

Types of Speech Acts Performed by the Teachers

\begin{tabular}{l|l|l|l|c}
\hline \multicolumn{1}{c|}{ Assertive } & \multicolumn{1}{c|}{ Directive } & Commissive & \multicolumn{1}{c}{ Expressive } & Performative \\
\hline acknowledging & asking & -- & praising & ---- \\
- telling & commanding & & cheering & \\
- affirming & inviting & appreciating \\
- commenting & confirming & blaming & \\
& prohibiting & & teasing \\
& & & greeting & \\
\hline
\end{tabular}

On the other hand, the responses given by the students towards the teachers' initiative moves are of two types. In general, the children with light condition of autism verbally contribute a speech act of answering to respond to the teachers' questions--for instance the answers given by a child for the mathematic problems given by the instructor. In addition, the responses to the commands are realized in two ways. The first is a verbal response to a command in which the child counts the teacher's fingers for a mathematic problem provided by the teacher. On the other hand, a non verbal action is executed to respond to a command demanding a physical action such as holding a pen, noting down an answer, and so on. The latter mode is also performed by other children to accomplish the instructions their teachers gave. This phenomenon happens in a slightly different case with other kind of speech act such as a refusal. When a child executes an act of refusing, he tends to delivers it in non-verbal behavior such as standing still, or running around the classroom, or grabbing his teacher's hands, and so on. Another child represents his refusal by crying in combination with one of such physical actions. The table below demonstrates the types of speech acts done by the children in the interaction.

Table 3

Types of Speech Acts Performed by the Children

\begin{tabular}{l|l|l|l|l}
\hline \multicolumn{1}{c|}{ Assertive } & \multicolumn{1}{c|}{ Directive } & Commissive & \multicolumn{1}{c}{ Expressive } & Performative \\
\hline Answering & ---- & Non-verbal & ---- \\
Verbal Complying with & & & \\
refusing & \\
$\begin{array}{l}\text { Non verbal complying } \\
\text { with a commanding }\end{array}$ & & & & \\
\hline
\end{tabular}


In relation to the politeness strategies, the teachers showed similar pattern of choice in their interaction. They tend to execute the speech acts in bald on record, especially for the kid who is in a poor condition of autism. For certain condition, a learning process only has a target to make a child respond to an intiating move executed by the teacher. The expected responses depend on the children intelligence-children with poor condition are only expected to give non verbal response, while those with better one are designed to give verbal as well as non verbal behavior.

In addition to such a choice, they also performed positive and negative politeness strategies. Of fifteen positive politeness strategies suggested by Brown \& Levinson (1987), only three which were often exploited by the teachers in controlling the children, i.e. using in-group markers, attending the children interest and wants, and giving approval to the children ability and performance. One of the way the first strategy was executed was by mentioning the name of the children in interaction such as Marcel berdiri ("Marcel stand"). The other forms of in-group marker are using the teacher's names to replace a pronoun referring to her, e.g. Ayo berikan bu Dini ("Come on, give it to Miss Dini") instead of saying Ayo berikan ke aku ("Come on, give it to me") and tossing - in which the teachers inviting the kids to toss to celebrate good performances they had showed.

Another positive politeness strategy which was much exploited by the teachers toward the children is attending the kids' interest by asking them what they would like to learn in that session. This strategy gets supported then by the choice of speech acts of acknowledging and accepting the answer of the kids to questions given to them. This strategy was often combined with praising or a compliment to their performance. All the strategies which are related to the children positive face above were selected and executed by the teachers to encourage them to perform more. They are believed to increase their self-esteem so that the process of the next learning would expectedly go better.

Meanwhile, the teachers also conducted politeness strategies related to negative face of the children. As this kind of politeness suggests that no one wants to be impeded or burdened, they tried to be indirect in giving the commands and to minimize the imposition delivered to the children. The former was mostly performed by arranging the command in a passive declarative sentence such as, Ayo apelnya dihitung. ("Come on, the apples are counted"). With this strategy, the teachers tried to decrease the potential of the utterance to be face threatening toward the children. Meanwhile, the latter strategy was conducted by repeating questions or problems or requests for actions that were assigned to the kids. Such a strategy was also executed by reducing the pace of the speech in giving the questions or problems or requests for actions such as Ber-di-ri! ("Stand!") instead of Berdiri! ("Stand!"). For assignments that were considered too hard for the kids to perform, the teachers tended to give them guidance such as by providing the answers part by part. For example, a teacher uttered Li.....ma ("Five") slowly which was presented as a guidance for one of the kids for a counting problem Ini berapa Farid? ("How many Farid?" as one teacher showed five fingers to the kid). The following table presents types of super strategies for politeness performed by the teachers towards the children with autism.

Table 4

Types Superstrategies for Politeness by the Teachers

\begin{tabular}{ll}
\hline \multicolumn{1}{c}{ Positive Face } & \multicolumn{1}{c}{ Negative Face } \\
\hline $\begin{array}{l}\text { in group markers } \\
\text { attending interest } \\
\text { giving approval }\end{array}$ & be indirect \\
minimize the imposition
\end{tabular}

In relation to the non verbal behavior in the interaction, the teachers demonstrate body language and facial gestures combined with the verbal resource. For example, one teacher uses her fingers in most of the exchanges she initiates for the supporting the mathematic problems for the child. In addition to this, she also performs several physical actions along with the commands she delivers to the child such as providing a note book for the child after she commands him to write down the answer of a problem, or giving him a pen after commanding him to hold the pen, and so on. The other teacher performs another strategy in doing her job, such as touching an object to the kid's hand and moves the thing up and down his hand so 
that he is stimulated to say the name of the object. The other non verbal mode is facial gestures. The teachers always make eye contact to the children while they are initiating and interacting with him. This is done to show emotional relationship between the teachers and the kids, which in turn will increase the children self confidence in experiencing the learning process. The actions performed by the teachers in supporting the learning process above may represent strategies in showing their positive as well as negative face politeness toward the children. None of them shows bald on or off record politeness strategies. The table below presents actions performed by the teachers in showing their politeness strategies

Table 5

Non-Verbal Behaviors Representing Politeness Strategies

\begin{tabular}{|c|c|c|c|}
\hline \multicolumn{2}{|c|}{ Positive Face } & \multicolumn{2}{|c|}{ Negative Face } \\
\hline Strategy & Action & Strategy & Action \\
\hline In group marker & $\begin{array}{ll}\text { - } & \text { Touching } \\
\text { - } & \text { Eye contact }\end{array}$ & Minimizing the imposition & $\begin{array}{ll} & \text { Providing fingers for calculation } \\
\text { - } & \text { Providing a note book for a } \\
\text { command of writing colors } \\
\text { - } \quad \text { Giving a pen after commanding } \\
\text { for holding a pen } \\
\text { - } \quad \text { Showing and touching an object } \\
\text { to stimulate the kid to say the } \\
\text { name of the object }\end{array}$ \\
\hline Giving approval & $\begin{array}{ll}\text { - } & \text { Tossing } \\
\text { - } & \text { Cheering }\end{array}$ & & \\
\hline
\end{tabular}

Seen from the grammar quality, most of the speech acts perfomed by the teachers are realized in mood structure in the form of elliptic construction. For example, to deliver a question for a mathematic problem that might be Berapa empat tambah empat? ("What is four plus four?"), the teacher only says Berapa ini? ("How many?"). Even though this interrogative sentence is ellipted, the meaning is systemically provided from the supporting non verbal behavior such as the fingers forwarded to the child while she is providing the elliptic question, or from the intonation going along with the question such a rising intonation for Empat tambah empat? ("Four plus four?"). This case also happens to the construction accommodating a command, such as the utterance of Tulis! ("Write!"), which should be completely arranged to have its object, such as Tulis namamu! ("Write your name!"). In addition, the grammar for this speech act also depends on the transitivity of the verb selected for the utterance. If it is a transitive verb, the construction tends to appear to be a verb and its object only such as, Ambil pensil! ("Get the pencil!"), but if it is a transitive one-it tends to appear in one verb only such as Duduk! (“Sit!”), or Merangkak! (“Crawl!"), and so on.

Types of speech acts and the politeness strategies as well as grammar quality above are deliberately designed by the teachers to have politeness strategies to the children. Of four politeness strategies suggested by Brown \& Levinson (1987) off-record is not selected at all by the teachers due to the consideration of the children autism condition. In their mind, indirect forms and implied intention will not work for the kids. On the other hand, the exploitation of three other politeness strategies in general give suggestion that in controlling children with such a condition the teachers perform the transfer process in direct way. Moreover, they tend to very often praise, appreciate, and congratulate the children in relation to their performance. These positive strategies are executed to increase the children self-esteem and to enforce the process of learning.

To make the exchanges more effective the teachers also exploits paralinguistic aspect for most of the speech acts they perform. For expressions building the interaction, a normal pace of the speech is chosen by the teachers, while for the important part of the communication, such as everything related to the skill being trained, a slow pace of speech is selected to adjust to the speed of the children decoding the message conveyed by the utterances. A teacher, for example, cuts the words into syllables such as ma-te-ma-ti$k a$ (mathematics), em-pat (four), li-ma (five), 
me-rang-kak. (crawl), and so on. Moreover, the teachers also skillfully perform non-verbal behavior in combination with the verbal as well as the paralinguistic ones.

Non-verbal actions in the interaction really may represent politeness strategies performed by the teachers. Actions such as touching the kid's cheek or forehead or hand, or tossing with him are example of positive politeness strategies to shorter the social distance between a teacher and a child. The strategies exploit in group marker to show solidarity. On the other hand, the action of a teacher in touching an apple and moving is up and down on a child hand is an example of negative politeness strategy to minimize the imposition of an instruction having been given to such a kid. Therefore, the collaboration of verbal and non verbal behavior of the teachers in presenting politeness strategies works effectively in supporting them handling their jobs. This is in line with what Rahardi (1999) has suggested that linguistic resources may accommodate politeness strategies in several forms such as the length of the utterance, the order of the utterances, the intonation and body language as well as the linguistic markers for such strategies. All of these forms were exploited by the teachers in this research in considering the best way to treat the children with autism in their learning process.

As types of speech acts and politeness strategies selected by the teachers show similarity, the paralinguistic aspects in executing the acts have different qualities from one teacher to the other. Such aspects are represented by the intonation, loudness, pitch as well as tones for each speech act, and these are selected in consideration to the condition of each child. In general, a child with serious autism governs his teacher to exploit sharper intonation, tone, and pitch as well as higher loudness for each utterance she executes for him compared to those with a light autism. These different qualities are also exploited for their non verbal behavior in their interaction. A teacher for the former child showed harder physical actions during the learning process to the child such as holding his hand, dragging the boy to do a certain action having been instructed, and so on. Even though all these actions can be considered to represent politeness strategies for the child's negative face-in that she tried to help him perform the task given to him (thus the teacher was trying to minimize the imposition to the kid), her non verbal behavior seems to be ruder compared to the same behavior performed by a teacher who is responsible for a child with a lighter autism condition. On that account, simply it can be suggested that the more serious a child is the ruder the physical action performed by the teacher toward him, and inversely-and the teachers designed and performed these non verbal behaviors on purpose. They know better what the best to do to the children under their responsibility.

As elaborated above, each learning process in this research is to transfer skills and knowledge to children with autism. However, the cognitive condition of the children influences the portion of the material being presented to the kids. The transfer of skills and knowledge in the learning process starts from simple to complicated materials adjusted to the level of the children intelligencethe better the condition the higher materials given to the kids and inversely. For instance, calculating skill is given to a child with the former condition. To such a kid the teacher introduced the concept not only of numbers but also of addition in one learning session. In this learning process, the teacher executed many commands in more polite strategy and also softer paralinguistic aspect. The politeness strategy can be seen from the expression of ayo initiating many commanding utterances - which really shifts such commands to become invitations and these sound politer to the children than the commands as the former provides options for the hearer to comply with it or not. The collaborative exploitation of verbal and paralinguistic aspects above is further supported by the non verbal behavior performed by the teachers-and this aspect plays the main part in representing the politeness strategies for the children negative face.

Meanwhile, the teacher for the child with severe autism gave materials which mainly focus on semantic concepts of physical actions such as to see, to touch, to give and to pick; concepts of names of things/ objects; names of organ of the body; and also concepts related to states such as soft, rough, and colors. To such a kid, the learning session is mainly designed for transferring psychomotoric 
skills. The teacher who is responsible for the kid selected basic physical actions for the learning materials such as to sit, to crawl, to put a thing in a jar - and actually this material is not only used to train the physical skills but also to introduce the semantic concepts for such actions.

\section{CONCLUSION}

The multimodal language exploitation in the learning process of children with autism in this study is demonstrated by the types of speech acts, the grammatical construction, the body language, facial gestures, the paralinguistic aspect of each utterance as the realization of an act, and also the politeness strategies performed by the teachers in executing an act. The speech acts are selected to be accommodated in one turn which is then conveyed in an exchange. In all exchanges the teachers take the initiative. The exploitation is considered to be effective as the teachers succesfully control the children to respond to the initiating acts of the teachers appropriately-both in the verbal and non verbal mode.

\section{REFERENCES}

Brown, P. \& S. C. Levinson (1987). Politeness: Some universals in language usage. Cambridge: Cambridge University Press.

Eggins, S. (1994). An introduction to Systemic Functional Linguistics. London: Pinter Publishers.

Fletcher, E. C. \& Schuler, A.L. (2003). Making communication meaningful (cracking the language interaction code) In Autism-from research to individualized practice. (ed. Gabriels, Robin,L and Hill, Dina, E). London: Jessica Kingsley Publishers.

Gerot, L. \& Wignell, P. (1995). Making sense of functional grammar. Cammeray: AEE.

Halliday, M.A.K. (1994). An introduction to functional grammar. London: Edward Arnold.

Hill, D.E. \& Kodituwakku, P. (2003). Neuropsychology of autism (research, theory, and practical implications) In Autism-from research to individualized practice (ed. Gabriels, Robin,L and Hill, Dina, E). London: Jessica Kingsley Publishers.

Levine, P. \& Scollon, R. (eds). (2004). Discourse and technology: multimodal discourse analysis. Washington: George University Press.

Pamuji. (2007). Model terapi terpadu bagi anak autisme. Jakarta: Departemen Pendidikan Nasional Direktorat Jenderal Pendidikan Tinggi Direktorat Ketenagaan.

Rahardi, R. K. (1999). Imperatif dalam Bahasa Indonesia: Penanda-Penanda Kesantunan Linguistiknya. In Jurnal Humaniora, Vol. XI, No. 2, 1999.

Safaria, T. (2005). Autisme: pemahaman baru untuk hidup bermakna bagi orang tua. Yogyakarta: Graha Ilmu.

Schuler, A.L. \& Fletcher, E.C. (2003). Making communication meaningful: cracking the language interaction code. In Autism-from research to individualized practice .(ed. Gabriels, Robin, L and Hill, Dina, E). London: Jessica Kingsley Publishers.

Shulman, C. (2003). Bridging the process between diagnosis and treatment. In Autism-from research to individualized practice.(ed. Gabriels, Robin, L and Hill, Dina, E). London: Jessica Kingsley Publishers.

Thomas, J. (1995). Meaning in Interaction: an introduction to pragmatics. London: Longman

Verschueren, J. (1999). Understanding pragmatics. London: Arnorld

Wenar, Charles. (2004). Developmental psychopathology: from infancy through adoleslence. New York: McGraw Hill.

Wetherby, A.M., Prizant, B.M. \& Schuler, A.L. (2000). Understanding the nature of language and communication disorder, In A.M. Wetherby \& B.M. Prizant (eds) Communication and language issues in autism and pervasive developmental disorder: a transactional developmental perspective. Baltimore, MD: Paul H. Brook 